\title{
Gambaran Memaafkan (Forgiveness) pada Korban Bullying
}

\author{
Azni Chaerunisa Utami ${ }^{1}$, Ulfiah ${ }^{1}$, Tahrir ${ }^{1}$ \\ ${ }_{1}^{1}$ UIN Sunan Gunung Djati Bandung
}

DOI: http://doi.org/10.29080/jpp.v\%vi\%i.232

\begin{abstract}
Forgiveness is not only attitude handling negative things as a result of hurt feeling but also an effort to avoid judgment against a guilty individual. This study focused on forgiveness by late adolescents who became victims of bullying. This is qualitative research with victim 20-year-old who has been bullied for two years at senior high school. Results showed that forgiveness is more dominant in the intrapsychic dimension or emotion and cognition. Meanwhile, in interpsychic dimension subject has not completely forgiven in social action. It was concluded that the subject was still in hollow forgiveness. Suggestions for further research are expected to find more sources and before taking data.
\end{abstract}

Keywords : Forgiveness, Bullying, Adolescents

\begin{abstract}
Abstrak : Memaafkan adalah sikap mengatasi berbagai hal negatif akibat dari rasa sakit yang dirasakan serta upaya menghindari penghakiman terhadap individu yang bersalah. Penelitian ini melihat gambaran memaafkan pada remaja akhir yang menjadi korban bullying. Penelitian ini merupakan penelitian kualitatif dengan subjek seorang remaja akhir berusia 20 tahun yang pernah mengalami tindak bullying selama dua tahun ketika di sekolah menengah atas. Dari hasil analisis wawancara, disimpulkan bahwa dalam pemaafan yang dilakukan subjek, lebih dominan dalam dimensi intrapsychic atau emosi dan kognisinya namun dalam tindakan sosial subjek belum memaafkan seutuhnya. Hal ini menunjukkan bahwa subjek berada dalam hollow forgiveness. Saran untuk penelitian selanjutnya diharapkan untuk mencari referensi sumber yang banyak sebelum melakukan pengambilan data.
\end{abstract}

Kata kunci : Memaafkan, Bullying, Remaja

\section{Pendahuluan}

Fenomena kekerasan semakin marak terjadi di berbagai seting seperti lingkungan kerja, keluarga, pertemanan, organisasi dan pendidikan. Kekerasan di lingkungan pendidikan dapat dilakukan oleh siapa saja baik guru pada murid, murid kepada guru, dan bahkan sesama murid. Kekerasan yang dilakukan sesama siswa dapat berupa tindak 
memalak uang, memukul, mengasingkan teman maupun memberikan celaan yang tidak pantas. Jenis-jenis kekerasan tersebut dikatageorikan sebagai tindak bullying. Tindak bullying di lingkungan pendidikan memiliki catatan yang cukup tinggi. Data dari Internation Center for Research on Women (ICRW) menunjukan 84\% anak Indonesia mengalami kekerasan di sekolah dan kasus bullying tersebut mengalami peningkatan dari 67 kasus pada 2014 menjadi 79 kasus di 2015. Menurut Ketua KPAI, Asrorun Ni'am Sholeh peningkatan jumlah angka kekerasan di sekolah mengindikasikan faktor lingkungan yang tidak kondusif bagi perlindungan anak.

Tindakan abusive (kasar atau kejam) yang terjadi akibat ketidakseimbangan kekuatan antara pelaku dan korban ini terjadi karena terdapat fakto pendukung mengapa seseorang menjadi pelaku tindak bullying. Menurut Ulfiah (2018) karakterisitk pelaku bullying muncul karena enam hal yaitu kurangnya atau tidak memiliki empati, keterampilan interpersonal yang buruk, tidak terampil dalam mengendalikan diri, kurang beratanggung jawab dan memiliki pola perilaku impulsif-agresif. Ada sejumlah faktor yang menyebabkan seseorang menjadi korban tindak bullying seperti pola asuh orang tua yang sangat protectif, kepribadian individu tersebut, dan juga pengaruh media sosial. Akibat tindak bullying akan berdampak bagi pelaku maupun korban. Dampak negatif akan banyak dialami oleh korban bullying dimana korban yang mendapatkan tindak bullying fisik aktif akan mendapatkan lebam dan luka pada tubuh. Selain fisik, dampak lainnya akan memengaruhi area psikologis karena korban kemungkinan akan mengalami gangguan penurunan pada harga diri dan kepercayaan diri, kesepian, kecemasan, hingga depresi. Selain itu, bullying juga dapat menghambat aktualisasi diri. Dampak yang lebih buruk pada korban adalah adanya keinginan mengakhiri hidup mereka sebagai akibat dari depresi yang ekstrim dan kesepian.

Apabila tindak bullying ini terjadi di lingkungan sekolah, tentu saja akan berdampak pada sejumlah masalah seperti sulit konsentrasi di kelas, kemampuan daya ingat yang berkurang, penurunan prestasi akademik, dan membolos dari kegiatan belajar mengajar. Selain itu, dampak dalam jangka panjangnya akan membuat penyesuaian diri korban terhadap sosialnya semakin buruk, ingin pindah atau keluar dari sekolah karena yang mereka pikirkan adalah bagaimana caranya untuk menghindari pelaku bullying. Dampak negatif bullying tidak dapat dihindari, namun coping strategy yang dapat mengurangi dampak negatif dan membawa lebih banyak dampak positif adalah memaafkan. Memaafkan merupakan kesediaan menanggalkan kesalahan yang dilakukan oleh seseorang yang telah menyakiti hati atau melakukan suatu perbuatan salah (M. McCullough \& Emmons, 2003).

Sejumlah faktor-faktor dapat memengaruhi seseorang untuk melakukan pemaafan pada seseorang yang telah menyakiti. Penelitian Utami (2016) melihat adanya hubungan positif yang sangat signifikan antara hubungan kepercayaan interpersonal dengan pemaafan dalam hubungan persahabatan. Kepercayaan interpersonal mendorong individu mau memberikan maaf kepada sahabat yang telah melakukan kesalahan dikarenakan iba atau kasihan, keinginan untuk berinteraksi dengan lebih baik dan beradab. Selain itu, individu memberikan maaf dikarenakan sahabat tersebut perhatian, tidak memikirkan diri sendiri, memiliki sikap peduli terhadap orang lain, dan dapat diandalkan. Namun meskipun memaafkan memiliki dampak positif yang dapat mengurangi stress dan dampak negatif lainnya dan mengalihkannya menjadi motivasi positif, jarang sekali ditemukan korban yang dapat melakukan proses memaafkan ini. Secara umum, korban dari tindak bullying kesulitan untuk memaafkan sang pelaku.

Peneliti menemukan fenomena bullying yang terjadi pada gadis berusia 15 tahun dan telah mengalami bullying sejak duduk di bangku Sekolah Menengah Atas (SMA). Hal ini berawal ketika korban naik kelas sebelas atau setara kelas dua sekolah mengengah atas, di jurusan IPS. Awalnya hal yang dilakukan mereka masih sebatas bermain-main, 
seperti mengganggu korban ketika membaca dengan cara mengambil bukunya, mengejeknya namun itu masih bisa diterima oleh korban karena sikap teman-temannya cenderung suka bercanda. Tapi lama kelamaan, candaan yang dilontarkan sudah keluar batas, dan korban yang awalnya hanya mengabaikan setiap tindakan yang diberikannya merasa sudah tidak tahan, dan mulai meluapkan emosinya.

Teman laki-laki korban cenderung bermain secara fisik dan diluar batas kewajaran. Mereka melibatkan fisik seperti memukul kepala korban, mendorongnya, menarik kerudung yang korban gunakan, hingga memaksa korban memakan makanan yang tidak disukai korban. Selain itu para teman laki-lakinya tak jarang melontarkan kalimat-kalimat tidak menyenangkan, menyindir dengan kalimat yang merendehkan, bahkan melecehkan bentuk tubuhnya. Tidak hanya teman laki-laki yang bertindak demikian tetapi juga siswa perempuan di kelasnya. Apabila laki-laki melakukan tindakan secara fisik, maka lain halnya dengan para perempuan yang lebih ke relasional. Mereka menjauhinya di kelas, dan mengasingkannya seorang diri. Kerap kali teman-temannya melemparkan tatapan sinis kepadanya, dan tidak mengikutsertakannya apabila merekamereka sedang berkumpul. Teman-temannya juga tidak membantunya ketika korban melewati masa sulitnya, dan cenderung mentertawakannya. Seperti saat korban terlambat masuk sekolah dan dihukum untuk memberi hormat pada bendera merah putih di tengah lapangan saat jam istirahat, mereka malah mentertawakan korban dengan begitu keras dan meledeknya. Mereka juga melontarkan kalimat-kalimat yang justru menurunkan motivasi korban seperti "emang kamu bisa?"

Tindakan-tindakan tersebut seiring berjalannya waktu tidak dapat ditolerir korban, akibatnya korban merasa sakit hati mendapatkan perlakukan seperti itu. Selain itu, akibat tindakan yang diterimanya, korban merasa rendah diri, merasa tidak berharga hingga membuat korban memilih untuk bolos dari sekolah agar tidak bertemu temantemannya, korbanpun pernah bercerita dengan orangtuanya, namun orangtuanya mengabaikan permasalahannya seolah bukan permasalahan besar dan berarti, sebaliknya, orangtuanya menyalahkan anaknya, karena seseorang tidak mungkin berbuat yang bermacam-macam apabila dirinya tidak banyak bertindak. Maka korbanpun lebih memilih untuk berdiam diri, tidak lagi bercerita pada siapapun.

Selama tindak bullying yang diterimanya, korban menghindari masalah dengan membolos dari kelas agar tidak bertemu dengan teman-temannya dan mendapatkan tindak seperti itu lagi. Respon yang diberikan dengan melawan meski pada akhirnya korban akan menangis, semakin korban bertindak semakin teman-temannyapun lebih memperlakukan korban dengan tidak baik. Pada akhirnya ketika kelas dua belas saat teman-temannya masih memperlakukan korban dengan sama, korban ingin merubah dirinya sendiri dengan yang awalnya menghindari masalah, dan membiarkan dampak negatif membelenggu dirinya, ia saat itu ingin membuktikan diri pada teman-temannya bahwa dia tidak pantas diperlakukan seperti itu dan membuatnya tidak dianggap remeh oleh teman-temanny. Salah satunya dengan cara membalasnya dengan prestasi yang cukup meningkat dibanding sebelumnya.

Ketika mendekati akhir kegiatan belajar, korban yang biasanya akan merespon tindakan yang diberikan teman-temannya dengan cara marah atau menangis, ketika kelas dua belas dia mencoba mengabaikan tindakan mereka masih terus berlanjut. Hal itu menjadi awal bagi korban untuk memaafkan teman-temannya, bermula ketika guru sosiologi menyadari ada sesuatu di kelas. Guru memanggil korban dan meminta untuk menceritakannya tetapi korban tidak menceritakan secara rinci dan hanya menutupi bahwa teman-temannya hanya bercanda. Mendekati perpisahan, guru meminta temantemannya meminta maaf apabila terdapat hal tidak menyenangkan pada temannya satu sama lain. Beberapa anak awalnya hanya diam, lalu teman laki-laki lainnya mulai melangkah mendekati korban dan meminta maaf. Lantas teman lainnya menyahut "aya 
kawani teu? Ari aya mah hayu" ("ada keberanian ngga? Kalau ada mah ayo kita minta maaf"). Satu per satu mereka mendekatinya dan meminta maaf, meski saat itu dari pihak pelaku atau teman-temannya hanya meminta maaf dengan tidak serius dan begitupun korban yang hanya memberikan kalimat maaf meski dari hatinya tidak ada rasa untuk memaafkan, saat itu korban hanya ingin menyelesaikan masalahnya dengan cepat dan tidak lagi bertemu dengan mereka.

Meski telah mengucapkan kalimat maaf itu, ketika mereka kembali dipertemukan di tahun pertama mereka kuliah. Ketika buka puasa bersama, tindakan tidak menyenangkan itu kembali terulang, korban diasingkan dan tidak memiliki teman untuk berbicara, lebih buruknya teman laki-lakinya bahkan melakukan hal tidak menyenangkan dengan menatap kearah area dadanya, dan mengatakan hal tidak senonoh "wah gedean ayeuna mah." ("wah, besaran sekarang mah") dan kalimat tidak menyenangkan lainnya. Tentu saja hal itu membuat subjek tidak terima, dan semakin kesal. Mereka juga acap kali bertemu dengan tidak mengajak korban. Setelah sekian lama tidak bertemu, tahun berganti tahun, korban yang saat sekolah begitu pasif dan menutup diri, ketika di perkuliahan, korban mulai aktif mengikuti kegiatan keagamaan, pada satu saat membahas mengenai pentingnya menjalin silaturahmi sesama manusia. Menyadari bahwa hubungan dengan teman-temannya renggang akibat korban yang dengan sengaja menjauh dan memutus silaturahmi tersebut, merasa bahwa hal tersebut tidak baik untuk dirinya, dan bahkan hanya membawa rugi. Maka dari sana bermula keinginan subjek untuk menjalin kembali komunikasi, dan memaafkan masa lalunya untuk menghadapi masa depan yang lebih baik.

Fenomena tersebut menjadi unik bagi peneliti, ketika sebagian besar korban bullying masih terjebak dengan perasaan tidak menyenangkan dan dampak negatif lainnya, subjek justru memilih untuk memaafkan pelaku. Peneliti tertarik pada malasan mengapa korban memilih untuk melakukan coping strategy dengan metode memaafkan, bagaimana proses memaafkan pada korban bullying beserta hasil apa yang telah dirasakan. Hal tersebut penting untuk diteliti untuk mengetahui manfaat apa yang telah dirasakan subjek saat melakukan proses memaafkan karena itu coping strategy terbaik yang dilakukan untuk mengurangi dampak negatif seperti marah, ketakutan dan kecemasan itu menjadi dampak positif bagi diri.

\section{Bullying}

Menurut Olweus (dalam Prasetyo, 2011) bully memiliki arti menggertak dan mengganggu orang yang lebih lemah. Perilaku agresif seseorang atau sekelompok orang yang dilakukan secara berulang-ulang terhadap orang atau sekelompok orang lain yang lebih lemah untuk menyakiti korban secara fisik maupun mental adalah perbuatan bullying. Tindak bullying terbagi kedalam tiga kategori, yaitu bullying secara fisik, bullying secaar verbal dan bullying dalam hubungan (relasional). Bullying secara Fisik (Physical Bullying) adalah tindakan memukul, menendang, menampar, mencekik, menggigit, mencakar, meludahi, dan merusak serta menghancurkan barang milik anak yang ditindas. Adapun bullying secara Verbal (Verbal Bullying) yang meliputi julukan nama, celaan, fitnah, kritikan kejam, penghinaan, pernyataan-pernyataan yang bernuansa ajakan seksual atau pelecehan seksual, terror, surat-surat yang mengintimidasi, gosip dan sebagainya. Jenis tindakan bullying ini paling mudah dilakukan akan tetapi tidak mudah teridentifikasi, terkadang lingkungan menganggap hal tersebut wajar terjadi antar teman. Terakhir adalah Relasional Bullying yaitu bentuk pelemahan harga diri korban secara sistematis melalui pengabaian, pengucilan atau penghindaran. Pandangan agresif, lirikan mata, helaan nafas, cibiran, tawa mengejek dan bahasa tubuh yang mengejek merupakan bentuk sikap bullying. 
Olweus (dalam Beane, 2008) menjelaskan perbedaan pelaku bullying yang aktif dan pasif serta siapa yang menjadi korban bullying. Pelaku bullying agresif cenderung kuat secara fisik, impulsif, agresif, pemarah, tidak kenal takut, suka memaksa, percaya diri dan kurang memiliki rasa empati. Adapun pelaku bullying pasif cenderung tidak percaya diri dan tidak lebih populer dari pelaku bullying agresif. Mereka mempunyai self-esteem yang rendah, mempunyai beberapa kualitas yang disukai dan seringkali mempunyai kehidupan rumah yang tidak bahagia. Sementara mereka yang menjadi korban pelaku bullying adalah anak-anak yang pernah mengalami perlakuan bullying di rumah atau di sekolah. Korban tindak bullying terbagi menjadi tiga kelompok yaitu korban pasif, korban provokatif, dan korban pelaku. Korban pasif mewakili kelompok terbesar korban dan mereka muncul menjadi siswa yang secara fisik lebih lemah dan tidak bisa membela diri. Korban pasif ini memiliki sedikit teman dan mereka adalah anak-anak yang memiliki orang tua yang over protective. Sementara itu korban provokatif dapat menjadi agresif, terutama saat menghadapi orang lain yang lebih lemah. Mereka juga tidak disukai oleh teman-temannya karena memiliki keterampilan manajemen kemarahan yang buruk dan sering beraksi negatif terhadap konflik atau kehilangan. Terakhir adalah korban pelaku bullying yaitu anak-anak yang mengalami perlakuan bullying di rumah atau di sekolah, dan menjadi pelaku bullying saat bertemu anak yang lebih lemah.

Olweus (dalam Berthold \& Hoover, 2000) menyatakan bahwa bullying memiliki pengaruh yang besar bagi kehidupan korbannya hingga dewasa. Depresi dan perasaan tidak bahagia untuk mengikuti sekolah selalu dihantui oleh perasaan cemas dan ketakutan. Korban bullying cenderung memiliki self esteem yang lebih rendah dibandingkan anak yang tidak menjadi korban bullying (Olweus, Rigby, \& Slee dalam Aluedse (2006)). Swearer, Espelage, Vaillancourt, \& Hymel (2010) menambahkan bahwa korban bullying merasa sakit, menjauhi sekolah, memiliki prestasi akademik yang rendah, merasa takut dan cemas, serta adanya keinginan bunuh diri.

Islam juga memiliki pandangan tentang bullying dimana seorang muslim harus berusaha untuk mengerti, memahami serta mengenalkan Ukhuwwah Islamiyah yang benar sesuai dengan Al-Qur'an dan Al-Hadits. Rasulullah SAW bersabda diriwayatkan oleh Abu Hurairah sebagai berikut: "Janganlah saling mendengki, saling menipu, saling membenci, saling memutuskan hubungan dan janganlah sebagian kamu menyerobot transaksi sebagian yang lain, jadilah kalian hamba-hamba Allah yang bersaudara. Seorang hamba muslim yang lain tidak boleh mezhaliminya, membiarkannya, mendustainya dan tidak boleh menghinakannya." Islam juga melarang saling membenci. Asy-Syaikh Al"Allamah Al-Imam Muhammad Hayat As-Sindi Rahimatullah berkata "Jangalah kalian melalaikan apa yang akan menyebabkan saling membenci karena itu akan menyebabkan bermacam-macam kerusakan di dunia dan bencana di akhirat." Sedangkan, Al-Imam AlHafizh Rajab Al-Hambali berkata, "Sesama muslim dilarang saling membenci dalam hal selain karena Alah apalagi atas dasar hawa nafsu karena sesama muslim itu telah dijadikan Allah bersaudara dan persaudara itu saling cinta bukan saling benci."

Dalam hadis yang diriwayatkan tersebut, menggambarkan dengan gamblang bahwa Islam tidak menyukai perbuatan saling menyakiti antara sesama manusia karena pada dasarnya semua mukmin itu bersaudara. Semua kaum muslim dianjurkan untuk melakukan mu'amalah ukhuwah dengan menghendaki kebaikan untuk saudaranya dan membenci kejahatan pada saudaranya dan seperti yang menimpa dirinya. Akibat bullying yang akan memengaruhi kehidupan seseorang di masa depan, maka dampak negatif tersebut sebaiknya mampu dihilangkan dan diubah menjadi dampak positif bagi orang tersebut, salah satunya dengan memaafkan.

Menurut Enright (dalam M. McCullough \& Emmons, 2003), memaafkan adalah sikap mengatasi hal-hal yang negatif dan penghakiman terhadap orang yang bersalah dengan tidak menyangkal rasa sakit. Beumeister, Exline, dan Sommer (dalam 
Worthington, 1998) menjabarkan ada dua dimensi memaafkan yaitu dimensi intrapersonal dan dimensi interpersonal. Dimensi intrapersonal melibatkan aspek emosi dan kognisi dari pemaafan. Ada proses yang dilewati yaitu mulai dari mulai memaafkan sampai sepenuhnya memaafkan dan tidak ada lagi rasa marah atau dendam. Sampai akhirnya melakukan pemaafan. Rourke (2006) menambahkan bahwa pemaafan intrapersonal membuat korban berdamai dengan perasaan negatifnya.

M. McCullough \& Emmons (2003) mengatakan bahwa dimensi ini juga disebut pemaafan sepihak karena berdamai dengan emosinya sendiri, dan kebanyakan pemaafan ini terjadi dengan orang asing, atau dengan mereka yang tidak diinginkan untuk bisa melanjutkan hubungan lagi. M. E. McCullough, Emmons, \& Tsang (2002) mendefiniskan pemaafan interpersonal sebagai sejumlah perubahan motivasi seseorang yang menyebabkan berkurangnya motivasi untuk membalas dendam, menjaga jarak dengan pelaku, dan meningkatnya motivasi untuk berdamai dengan pelaku.

Adapun dimensi Interpersonal fokus pada satu perilaku yang mengekspresikan pemaafan. Perilaku tersebut seperti mengucapkan kata "Saya memafkan dirimu". Dimensi ini melibatkan aspek sosial dari pemaafan. Ini adalah langkah awal atau permulaan bagi korban untuk mengembalikan hubungan seperti kondisi sebelum terjadi pelanggaran oleh pelaku. Tujuan korban melakukan pemaafan interpersonal ini adalah agar pelaku tidak selalu merasa bersalah dan dengan harapan agar pelaku tidak lagi berusaha mencari cara berbaikan dengan korban. Namun, pemaafan yang dinyatakan secara verbal tetapi masih terus menyimpan sakit hati dan dendam (Wardhati \& Faturochman, 2010). Pemaafan interpersonal ada pada seting keadaan untuk membangun atau mendamaikan kembali hubungan yang telah ada (Rourke, 2006).

Ada empat fase pemberian maaf dijelaskan oleh Enright, Ancok \& Suroso (2008) yaitu pertama, fase pengungkapan (uncovering phase), ketika seseorang merasa sakit hati dan dendam, kedua fase keputusan (decision phase), dimana berpikir rasional dan memikirkan kemungkinan untuk memaafkan, ketiga, fase tindakan (work phase), yaitu adanya tingkat pemikiran baru untuk secara aktif memberikan maaf kepada orang yang telah melukai hati dan terakhir fase pendalaman (outcome/depending phase), yaitu internalisasi kebermaknaan dari proses memaafkan, ia akan memberi manfaat bagi dirinya sendiri, lingkungan dan juga semua orang.

\section{Metode Penelitian}

Penelitian ini menggunakan metode kualitatif studi kasus. Subjek penelitian ini adalah remaja akhir usia 20 tahun yang menjadi korban bullying selama dua tahun dan sudah memaafkan pelakunya. Metode pengumpulan data yang digunakan untuk pengumpulan data dalam penelitian ini adalah wawancara terstruktur yang didukung oleh observasi tingkah laku partisipan. Wawancara adalah percakapan yang dilakukan oleh dua pihak yakni pewawancara yang mengajukan pertanyaan dan terwawancara yang memberikan jawaban atas pertanyaan itu (Moleong, 2012). Observasi adalah pengamatan pencatatan secara sistematik terhadap unsur-unsur yang tampak dalam suatu gejala atau gejala-gejala pada obyek penelitian. Selama penelitian berlangsung, digunakan observasi tidak terstruktur, observasi yang tidak dipersiapkan secara sistemastis tentang apa yang akan diobervasi (Sugiono, 2010).

Agar peneliti dapat berkonsentrasi dengan pelaksanaan penelitiannya, maka digunakan pula beberapa alat bantu untuk merekam jalannya penelitian. Selanjutnya dilakukan analisis data menggunakan triangulasi yaitu teknik pemeriksaan keabsahan data yang memanfaatkan sesuatu yang lain. Diluar data itu untuk keperluan pengecekan atau sbagi pembanding terhadap data itu. Triangulasi yang digunakan dalam penelitian ini 
adalah triangulasi sumber untuk menguji kredibilitas data dilakukan dengan cara mengecek data yang telah diperoleh melalui sumber data (Sugiono, 2010).

Triagulasi dilakukan dengan (1) membandingkan data hasil pengamatan dengan data hasil wawancara; (2) membandingkan apa yang dikatakan orang di depan umum dengan apa yang dikatakannya secara pribadi; (3) membandingkan apa yang dikatakan orang-orang tentang situasi penelitian dengan apa yang dikatakannya sepanjang waktu; (4) membandingkan keadaan dan perspektif seseorang dengan berbagai pendapat dan pandangan; (5) membandingkan hasil wawancara dengan isi suatu dokumen yang berkaitan (Moleong, 2012).

\section{Hasil dan Pembahasan Penelitian}

Subjek merupakan seorang perempuan yang kini berusia dua puluh tahun yang mengalami tindak bullying ketika berada di bangku Sekolah Menengah Atas tepatnya ketika kelas sebelas. Awalnya pada kelas sepuluh, subjek digambarkan teman-temannya sebagai seseorang yang baik yang dapat berbaur bersama teman-teman yang lain dan memiliki pribadi yang hangat. Namun, ketika kelas sebelas saat kelas dipecah dan dibagi berdasarkan jurusan yang dipilihnya, subjek masuk pada jurusan IPS, berbeda dengan sahabatnya yang mengambil jurusan IPA. Saat itu, subjek mulai kurang dapat berbaur ditambah lagi bahwa hanya ada satu orang teman sekelasnya yang kembali dipertemukan di kelas yang sama. Memiliki kepribadian yang pendiam, keduanya hanya menjadi minoritas di kelas tersebut.

Pada awal semester, teman-teman barunya ini suka sekali bercanda, hanya saja bagi mereka respon yang diberikan subjek ini menyenangkan, mereka mulai terus menerus mengusik subjek, menganggunya, dan mulai mengejeknya. Subjek yang tidak terima dengan perlakuan tersebut menunjukkan perlawanan dengan berteriak dan marah, hingga pada akhirnya menangis. Namun, para teman laki-lakinya tersebut menganggapnya sebagai respon yang lucu yang membuatnya terus menerus menjadi objek bualan mereka, sementara respon yang ditunjukkan subjek tersebut justru memberikan persepsi yang berbeda untuk teman-teman perempuannya, subjek dianggap melakukan hal tersebut untuk menarik perhatian laki-laki.

Subjek bersama keempat temannya di kelas merupakan kelompok minoritas yang hanya berdiam diri dan tidak melakukan pembelaan ketika diperlakukan tidak adil seperti itu. Semakin hari, tindakan yang diterima subjekpun menjadi-jadi, tidak hanya lagi cemoohan yang dilontarkan, mereka mulai merendahkan korban dengan kata-kata tidak pantas seperti 'kampungan', 'si bau'. Verbal dan fisikpun diterimanya, para teman lakilakinya bahkan melakukan tindak fisik dengan mendorong kepala subjek, memukul punggung subjek tanpa alasan, bahkan melayangkan tinjuan kehadapan wajah subjek meski tidak mengenai wajahnya. Dalam tindak verbal, tidak hanya kata-kata yang merendahkan, bahkan mereka melecehkan korban dengan kalimat-kalimat tidak senonoh yang berkaitan dengan anggota tubuhnya, yang terkadang diiringi dengan pandangan yang mengarah pada bagian tubuh subjek dan menunjuknya dengan telunjuk mereka.

Hal yang diterima subjek tersebut tergolong pada tindak bullying yaitu bentuk perilaku agresif dimana seseorang dengan sengaja dan berulang kali menyebabkan orang lain cedera atau ketidaknyamanan. Bullying bisa berupa kontak fisik, kata-kata atau tindakan yang lebih halus. Bukti bahwa subjek mendapat tindak bullying juga didukung dengan membandingkan hasil wawancara yang diberikan $\mathrm{A}$ dan $\mathrm{F}$ pun menunjukan hal yang sama dengan yang diceritakan subjek, bahwa selama dua tahun subjek dijauhi teman-temannya secara relasi, selain itu juga $\mathrm{F}$ menjelaskan bahwa pernah suatu waktu teman-teman laki-lakinya itu mengejeknya karena subjek pernah menangis di dalam kelas karena suatu hal, dan mereka mengejeknya di setiap kesempatan sehingga membuat 
subjek menangis. Para teman-temannya, menurut F, hanya melakukan hal tersebut kepada subjek, sementara kepada teman-temannya yang lain, mereka biasa saja. Bahkan temantemannya sering kali mendorong kepala subjek dari belakang dan tertawa setelah melakukannya. Sementara menurut penuturan A, yang ia ketahui bahwa subjek hanya dijauhi teman-temannya karena dirasa berbeda dengan yang mayoritas siswa di kelasnya, dan juga saat A berjalan bersama subjek, teman-temannya tersebut dengan sengaja memberikan tatapan sinis pada keduanya.

Ketika secara aktif mendapatkan perlakuan tidak menyenangkan seperti itu, subjek seringkali bolos dari kegiatan belajar mengajar di sekolah untuk menghindari masalah, menghindari teman-temannya agar tidak diperlakukan demikian. Akibatnya, prestasi akademiknya menurun, perlakuan yang diterimanya semakin marah, semakin diejek oleh mereka dan semakin diasingkan. Selain itu juga, subjek merasa rendah diri, tidak berani untuk menjalin relasi dengan orang baru dan cenderung menutup diri selama sekolah. Setahun itu subjek menunjukan banyak reaksi ketika teman-temannya bersikap seperti itu; subjek pernah menangis, subjek pernah memanggil ayahnya untuk menjemputnya pulang, subjek pernah marah dengan cara diam atau dengan cara melawan kembali teman-temannya. Emosi dan reaksi yang diberikan subjek adalah wajar ketika mendapatkan perlakuan tidak adil seperti itu, dan subjek termasuk ke dalam jenis korban bullying pasif menurut Olweus dalam (Beane, 2008) yang menjelaskan bawa korban pasif mewakili kelompok terbesar korban, mereka tidak memprovokasi perilaku bullying, mereka muncul menjadai siswa yang secara fisik lebih lemah dan tidak bisa membela diri. Subjek melawan namun tidak mampu mempertahankan dirinya dari teman-temannya.

Keadaan mulai berubah ketika subjek menginjak kelas tiga sekolah menengah atas, dengan diri yang mulai sibuk untuk mempersiapkan ujian akhir, saat itu subjek mulai mencoba mengabaikan tindakan yang diberikan teman-temannya, meski masih aktif membullynya dengan melontarkan kalimat tidak menyenangkan, mendorong kepala korban, hal tersebut dicoba subjek untuk diabaikan, dan subjek mencoba menunjukkan dirinya bahwa ia tidak pantas diperlakukan seperti itu, bahwa subjek lebih baik daripada teman-temannya. Hal itu dapat ditunjukkan oleh subjek melalu prestasi akademiknya yang meningkat, ranking di kelas yang awalnya berada dibarisan rendah dapat diubah subjek dengan menduduki peringkat sepuluh besar dikelasnya. Saat itu, hal itu membuat subjek merasa puas.

Dengan tindakan kasar yang diterima teman-temannya, terdapat seorang guru yang menyadari tindakan tersebut, dan ketika kelas tiga tersebut sang guru mulai turun tangan dengan bertanya pada subjek mengenai apa yang terjadi, mengetahui cerita tersebut, guru itu berkata pada teman-teman subjek bahwa hal tersebut tidaklah pantas dilakukan dan memberi nasihat untuk meminta maaf pada siapapun yang dirasa pernah disakiti, mengingat juga bahwa mereka semua sebentar lagi akan berpisah dari sekolah menengah atas. Mendengar perkataan gurunya, kawannya tersebut memberanikan diri untuk meminta maaf pada subjek sambil mengajak teman-temannya dengan berkata 'aya kawani teu?' atau 'ada keberanian ga (untuk meminta maaf)?' lalu mereka semua mulai meminta maaf pada subjek meski dengan setengah hati dimana permintaan maaf diucapkan masih dengan bercanda. Saat itu subjek tidak begitu peduli dengan permintaan maaf tersebut, yang subjek inginkan hanya tindakan tersebut berhenti dan tidak terulang di kemudian hari.

Selepas perpisahan sekolah itu, subjek mulai memutus komunikasi dengan temantemannya, ia mengambil tempat kuliah yang jauh dengan harapan tidak lagi bertemu dengan teman-temannya dan berkomunikasi lagi dengan mereka, ia mulai mengganti nomor ponselnya, membuat social media baru yang jauh dari lingkungan sekolahnya. Saat itu ia benar-benar mencoba mengkubur masa lalunya. Tidak semudah membalik telapak tangan, keadaan yang dilaluinya diawal masa perkuliahan cukup sulit, subjek tidak mudah 
untuk mendekati kawan barunya, banyak ketakukan dalam dirinya untuk menjalin hubungan dengan orang baru, ia merasa rendah diri, ia ketakukan apabila orang baru itu tidak menyukai sifat subjek, takut mengetahui masa lalu subjek dan akan menjauhi subjek karena siapa dirinya di masa lalu, atau lebih parah apabila orang baru tersebut akan melakukan apa yang dilakukan teman-temannya di masa lalu. Hal tersebut juga tidak membaik ketika pada tahun 2015, teman-temannya mengadakan acara buka bersama sekaligus silaturahmi, subjek awalnya menolak untuk datang karena belum siap untuk bertemu mereka dan takut mendapat hal yang tidak menyenangkan lagi. Akan tetapi, teman subjek memaksanya utnuk datang dan menemaninya. Hari itu tiba, subjek datang ke tempat yang telah ditentukan, dan saat itu kawannya tidak datang, dengan situasi yang lebih buruk saat teman-temannya kembali melakukan hal yang tidak wajar dengan mengejeknya dan menatap bagian atas subjek dengan melontarkan kalimat 'wah gedeaan ayeuna mah (dada)'. Setelah kejadian itu, subjek memantapkan diri untuk tidak lagi menjalin hubungan dengan teman-temannya karena hanya membuatnya semakin sakit hati. Dalam Islam, tindakan seperti itu tentu saja tidak dibenarkan, Islam melarang umatnya saling membenci dan seorang hamba muslim yang lain tidak boleh menzhaliminya.

Lalu waktu bergulir, pada tahun 2016, subjek mengambil cuti dari kuliah. Dalam jangka waktu tersebut, tidak banya aktivitas yang dilakukan subjek, setiap harinya yang dilakukan subjek hanya merenung. Salah satunya tentang dirinya yang berada di lingkungan rumahnya sendiri, di kampung halamannya, namun tidak memiliki teman untuk diajak bermain atau bertemu. Selain itu juga, ia mengikuti kajian keislamaan yang saat itu membahas topik pentingnya bersilaturahmi dan menjaga ukuwwah islamiyah, didukung kajian yang diikutinya itu memperkuat pemikiran subjek mengenai hubungannya bersama orang banyak yang tidak bertahan lama, bahkan tidak ada komunikasi yang berlanjut. Hal tersebut menyadarkan subjek bahwa semua ini terjadi akibat subjek yang memiliki kemampuan komunikasi yang kurang, subjek yang tidak bias mempertahankan hubungan dengan orang banyak.

Setiap harinya ia mengikuti kajian-kajian keislamaan, dalam titik terendahnya saat itu, memikirkan relasi dengan orang banyak yang terputus menjadi sebuah tamparan besar bagi diri subjek, ia menyesali banyak macam hal, dan menjadi pemicunya akan masa lalunya yang selalu subjek tekan ke alam bawah sadar. Saat itu, subjek menyadari bahwa hubungan terburuknya yang akhirnya kandas adalah dengan teman semasa sekolah menengah atasnya. Meningat teman-temannya dan tindakannya di masa lalu, memicu kembali perasaan saat itu, seperti emosi marah, sedih, kesal, dan perasaan negatifnya. Ini merupakan tahap awal dalam proses memaafkan yang dituturkan oleh Enright, yaitu fase pengungkapan atau uncovering phase, fase ketika seseorang merasa sakit hati dan dendam ketika mengingat kembali suatu kejadian di masa lalu. Meski dalam situasi ini subjek belum ada keingingan untuk memaafkan, namun ini merupakan tahap awal bagi subjek untuk memaafkan teman-temannya.

Setelah fase memicu kembali perasaan di masa lalu, subjek pada tahap ini mulai berpikir realistis, ia memahami bahwa perasaan negatif dalam dirinya hanya merugikan dirinya sendiri. Ia berpikir, selama ini yang dilaluinya seorang diri seperti terbelenggu perasaan negatif, memutuskan silaturahmi dengan teman-teman sekolahnya, menghindar dari mereka, itu semua tidak ada gunanya dan merugikan diri sendiri, sementara temantemannya tersebut belum tentu merasakan hal yang sama, belum tentu mereka terpengaruhi akan kejadian di masa lalu. Ini merupakan fase keputusan dalam proses memaafkan yang dialami seseorang yaitu fase dimana orang tersebut mulai berpikir rasional dan memikirkan kemungkinan untuk memaafkan. Ini dialami subjek setelah berpikir demikian, didukung oleh kajian keislaman yang diikutinya, menerangkan bahwa selain pentingnya menjaga silaturahmi, penting juga untuk memaafkan seseorang atas 
tindakannya yang menyakiti, untuk memberikan manfaat pada diri sendiri, orang banyak, dan juga menjadi awal untuk mengembalikan hubungan dan melangkan menuju masa depan yang baru.

Pada tahap inilah, subjek mulai ada keinginan untuk memaafkan teman-temannya dengan harapan utama yaitu mengembalikan silaturahmi. Tahap ini hanya tahap adanya keingingan belum memaafkan sepenuhnya, subjekpun memahami konsep memaafkan sebagai proses dimana seseorang mengikhlaskan dan berbesar hati atas perbuatan buruk orang lain yang menyakiti dan menimbulkan perasaan marah, kesal, seperti itu, dengan ikhlas kita lepaskan. apa yang diungkapkannya selaras dengan definisi yang dikemukakan M. McCullough \& Emmons (2003) bahwa memaafkan berhubungan dengan emosi, pikiran, dan tingkah laku, dan dampak penghakiman negatif terhadap orang yang menyakiti dapat dikurangi. Subjek juga selaras dengan konsep memaafkan yang dipahaminya untuk melepaskan segala emosi negatifnya, dengan menerima masa lalunya, dan menjadikan pengalamannya tersebut menjadi pembelajaran di masa yang akan datang. Dalam Islam orang bertaqwa meminta maaf sesama manusia agar terhindar dari sifat dendam yang dibenci Allah SWT. Dan seseungguhnya apabila manusia telah berdosa, yang dapat mengampuni dosa adalah Allah SWT, sehingga kita minta ampunan dari Allah SWT atas dosa kita tersebut. Dalam Surat An-Naml tersurat 'Hendaklah kamu meminta maaf kepada Allah, agar kamu mendapat rahmat'. Artian rahmat disini tentu saja kebaikan atau manfaat yang akan dirasakan seseorang setelah meminta ampun.

Selanjutnya menurut Enright, fase berikutnya dalam memaafkan adalah fase tindakan dimana ada tingkat pemikiran baru untuk secara aktif memberikan maaf kepada orang yang telah melukai. Dalam mewujudkan harapan subjek akan memaafkan tersebut, yakni mengembalikan hubungan dengan teman-temannya. Subjek mulai menjalin komunikasi dengan beberapa temannya, seperti saling follow mem-follow di sosial media, memberikan komentar dalam postingan temannya hingga berinteraksi dengan bertukar kabar di direct message. Ini merupakan tahap awal yang pasti yang dilakukan subjek untuk mencapai memaafkan yang sesungguhnya.

Selanjutnya, tahap akhir adalah fase pendalaman (outcome/depending phase), yaiu internlasisasi kebermaknaan dari proses memaafkan, ia akan memberi manfaat bagi diri sendiri, lingkungan dan juga semua orang. Dalam proses yang dilaluinya, memaafkan yang dilakukan subjek memang belum memaafkan sesungguhnya, namun dalam proses yang dilaluinya, terdapat manfaat yang dirasakan subjek yakni dengan mencoba memaafkan tersebut, seperti meningkatnya rasa percaya diri yang sempat menurun akibat bullying, , diungkap teman-temannya, subjek sudah mendapatkan kembali percaya dirinya dibanding ketika sekolah dulu, dimana subjek sudah mulai menginisiatif dengan membuka percakapan dengan orang, terbuka akan dirinya sendiri. Dengan memaafkan subjek menjadi lebih ringan tidak memiliki beban, dapat berkomunikasi dengan lingkungan sekitarnya tanpa ada yang harus disembunyikan, tanpa perlu takut bahwa lawannya mengetahui kelemahannya atau masa lalunya. Dan yang pasti, subjek dapat menerima masa lalunya dan tidak ada rasa ketakutan untuk menjalin kembali hubungan dengan teman-temannya dan untuk bertemu mereka kembal dan ketika berkomunikasi dengan teman-temannya subjek tidak merasakan adanya perasaan negatif seperti emosi marah, tidak ada perasaan untuk menghindar maupun balas dendam, dan hal positifnya subjek dalam berpikiran positif bahwa ia dan teman-temannya masih memiliki kenangan baik ketika semasa sekolah.

Selain proses memaafkan untuk mengetahui gambaran memaafkan, diteliti juga mengenai dimensi yang lebih dominan pada proses memaafkan yang dilakukan subjek dan menentukan kombinasi memaafkan mana yang sedang dilakukan subjek. Dalam memaafkan, terdapat dua dimensi menurut McCullough yaitu dimensi intrapsychic dan dimensi intrerpsychic. Dimensi intrapsychic adalah dimensi yang terdiri dari aspek emosi 
dan kognisi dari pemaafan. Rourke (2006) mengatakan bahwa pemaafan intrapersonal membuat korban berdamai dengan perasaan negatifnya. Dimensi ini disebut juga dengan pemaafan sepihak (M. McCullough \& Emmons, 2003), sebab prosesnya hanya dilakukan oleh pihak korban yang mencoba berdamai dengan emosinya sendiri, dan memiliki perubahan motivasi seseorang yang menjadi: (a) berkurangnya motivasi untuk membalas dendam, (b) berkurangnya motivasi untuk menjaga jarak dengan pelaku, (c) meningkatnya motivasi untuk berdamai dengan pelaku.

Apabila dikaitkan dengan kasus subjek, dalam hasil wawancaranya subjek terdapat perubahan yang pertama yaitu berkurangnya motivasi balas dendam. Subjek tidak pernah terdapat motivasi balas dendam dari sebelum hingga terjadinya pemaafan, yang membedakannya adalah alasan yang melatar-belakanginya. Apabila sebelum terjadinya pemaafan, alasan subjek tidak membalas dendam adalah karena tidak ingin terlibat dengan teman-temannya tersebut, setelah terjadinya pemaafan, subjek menyadari bahwa tidak ada manfaatnya, dan lebih memilih fokus menjalin hubugan baik bersama teman-temannya. Hal selaras pun disampaikan oleh kedua significant others dalam penelitian ini bahwa subjek tidak menunjukkan pemikiran maupun tindakan akan keinginan untuk balas dendam pada orang-orang yang terlibat dalam tindak bullying yang diterimanya.

Perubahan motivasi yang kedua yaitu berkurangnya motivasi untuk menjaga jarak dengan pelaku, dalam hal ini teman-temannya dapat dilihat dari subjek yang awalnya tidak memiliki keinginan untuk berkomunikasi dengan teman-temannya, menjadi salah satu alasannya untuk memaafkan adalah agar dapat menjalin silaturahmi dengan mereka. Dengan harapan bahwa hubungan kedua pihak tersebut dapat keep in touch, subjek menyadari bahwa dirinya harus yang mengambil peran terlebih dahulu. Disamping itu, ketika peneliti meminta subjek membayangkan situasi dimana dirinya bertemu kawan lama sekolah menengah atas, dalam keadaan disengaja maupun tidak sengaja, subjek berkata bahwa dirinya tidak akan menghindari situasi tersebut, malah subjek akan menjadi orang pertama yang menghampirinya. Hal ini juga menjadi pendukung untuk indikator selanjutnya yakni meningkatnya motivasi untuk berdamai dengan pelaku.

Sementara dimensi memaafkan selanjutnya, yaitu dimensi dimensi intrapersonal melibatkan aspek sosial dari pemaafan. Dalam kasus ini, subjek mengekspresikan pemaafannya dengan menjalin komunikasi lagi dengan teman-temannya, dan membangun kembali relasi yang lebih baik. Hal tersebut menjadi tujuan utama subjek dalam sikap memaafkan yang dimilikinya, selain hanya menjalin komunikasi melalui media sosial, subjek yang belum memiliki banyak kesempatan untuk bertemu dengan kawannya tersebut, merasa ingin untuk bertemu dan berbincang-bincang untuk menjalin hubungan yang lebih intim. Pemaafan interpersonal menurut Rourke pada tahun 2006, terkait pada keadaan untuk membangun atau mendamaikan kembali hubungan dalam kata lain membantu korban untuk merasa lebih baik.

Meskipun pemaafan ditandai dengan maaf secara verbal terhadap orang yang bersalah, namun sakit hati dan dendam masih tersimpan (Wardhati \& Faturochman, 2010). Subjek dalam kasus ini, belum memaafkan teman-temannya sepenuhnya dan masih mencoba untuk memaafkan sepenuhnya hal ini terlihat dari subjek yang memiliki rasa sakit hati ketika mengingat perbuatan teman-temannya, bukan lagi pada individu mereka. Meski demikian, subjek memilih untuk tidak mengingat kembali kejadian tersebut dengan mengalihkan pemikirannya dan hanya fokus membangun kembali relasi bersama temantemannya. Dengan demikian, proses memaafkan yang dilakukan subjek, dilihat dari dimensi intrapsychic masih berada pada tahap hollow forgiveness. Korban dapat mengekspresikan forgiveness secara konkret melalui perilaku namun masih menyimpan rasa dendam dan kebencian meskipun telah mengatakan "saya memaafkan kamu". 


\section{Simpulan dan Saran}

Berdasarkan gambaran memaafkan (forgiveness) yang dilakukan subjek L dapat disimpulkan bahwa terdapat dua dimensi dalam memaafkan (forgiveness), yakni intrapersonal yang lebih pada kognisi dan emosi, dan interpersonal yang cenderung pada tindak sosial. Dalam penelitian ini, tindak memaafkan subjek lebih dominan dibagian intrapersonal atau sebatas kognisi dan emosinya, subjek mampu mengendalikan emosinya dan merubah perasaan serta motivasi negatif menjadi positif, dengan adanya keinginan untuk berkomunikasi dan bertemu kembali dengan kawan-kawannya, menghilangkan rasa sakit hati maupun balas dendan. Dalam dimensi intrapersonal, tindak sosialnya, subjek belum secara aktif menunjukan sikap pada teman-temannya selain kembali berkomunikasi lewat sosial media. Sementara dilihat dari kombinasi kedua dimensi, subjek berada pada jenis hollow forgiveness, dimana subjek menunjukkan sikap telah memaafkan, meski sesungguhnya subjek baru mulai memaafkan dan belum sepenuhnya memaafkan.

Proses memaafkan terjadi ketika subjek mulai merasakan rasa sakit hati akibat tindak bullying yang diterimanya, ia menyadari dampak negatif dari tindak tersebut dan mulai memikirkan kemungkinan untuk memaafkan hal tersebut juga didukung oleh faktor eksternal yakni dengan subjek yang menerima kajian keislaman mengenai pemaafan dan manfaatnya untuk diri. Hingga hal tersebut membantu subjek untuk memaafkan segala tindak teman-temannya dan menerima masa lalu dirinya tersebut dan memungkinkan subjek untuk berkomunikasi kembali dengan nyaman bersama teman-temannya.

Selama proses memaafkan yang dilakukan subjek, subjek merasa terdapat manfaat yang dirasakannya. Subjek mulain menerima dirinya sendiri, ia tidak perlu takut untuk menunjukkan sifatnya pada orang disekitarnya tanpa perlu ada yang disembunyikan, subjekpun dapat terbuka dan mampu mengambil inisiatif untuk menjalin pertemanan dengan orang baru. Dan ketika berkomunikasi dengan teman-teman semasa sekolahnya, subjek tidak lagi terdapat beban yang membelenggu dan rasa takut.

Subjek diharapkan dapat lebih menerima tindakan yang pernah diterimanya, memaafkan diri, teman-teman dan masa lalu tanpa merasa sakit hati lagi. Subjek dapat menjalin hubungan yang lebih baik dengan teman-temannya tidak hanya melalui sosial media, namun juga merealisasikan yang sudah dipahamai oleh logika subjek dengan mengajak bertemu dan bercengkerama bersama, dan membuat harapan tersebut terwujud. Penelitian selanjutnya dapat memperbanyak sumber referensi sebelum melakukan penelitian terutama mengenai pembahasan pemaafan. Dirasakan selama penelitian, sumber referensi yang sedikit menjadi kendala selama proses penelitian. Selain dari itu, minim sekali penelitian mengenai pemaafan sehingga rujukan untuk melakukan penelitian selanjutnya, maka diharapkan peneliti selanjutnya untuk mencari sumber referensi lebih banyak untuk memudahkan memahami penelitian.

\section{Daftar Pustaka}

Aluedse, O. (2006). Bullying in schools: A form of child abuse in schools. Educational Research Quarterly, 30(1), 37.

Ancok, D., \& Suroso, F. N. (2008). Psikologi Islami; Solusi Islam atas Problem-problem Psikologi, Yogyakarta: Penerbit Pustaka Pelajar, cet.

Beane, A. L. (2008). Protect your child from bullying: Expert advice to help you recognize, prevent, and stop bullying before your child gets hurt. John Wiley \& Sons.

Berthold, K. A., \& Hoover, J. H. (2000). Correlates of bullying and victimization among intermediate students in the Midwestern USA. School Psychology International, 21(1), 65-78. 
McCullough, M. E., Emmons, R. A., \& Tsang, J.-A. (2002). The grateful disposition: A conceptual and empirical topography. Journal of Personality and Social Psychology, 82(1), 112.

McCullough, M., \& Emmons, R. (2003). Counting blessings versus burdens: An experimental investigation of gratitude and subjective well-being in daily life. Journal of Personality and Social Psychology, 84(2), 377-389.

Moleong, L. (2012). Metodologi Penelitian Kualitatif. Bandung: PT Remaja Rosdakarya.

Prasetyo, A. B. E. (2011). Bullying di sekolah dan dampaknya bagi masa depan anak. ElTarbawi, 4(1).

Rourke, J. (2006). Forgiveness-Seeking Motives and Behaviours. In Forgive-Ness, a Sampling of Research Results, 23-25. Washington DC: American Psychological Association.

Sugiono. (2010). Memahami Penelitian Kualitatif. Bandung: Alfabeta.

Swearer, S. M., Espelage, D. L., Vaillancourt, T., \& Hymel, S. (2010). What can be done about school bullying? Linking research to educational practice. Educational Researcher, 39(1), 38-47.

Ulfiah, U. (2018). Penanganan Perilaku Bullying Siswa Melalui Konseling Model Pengembangan Komitmen Beragama. Psympathic: Jurnal Ilmiah Psikologi, 1(1), 67-74. https://doi.org/10.15575/psy.v1i1.2120

Utami, D. A. (2016). Kepercayaan interpersonal dengan pemaafan dalam hubungan persahabatan. Jurnal Ilmiah Psikologi Terapan, 3(1), 54-70.

Wardhati, L. T., \& Faturochman. (2010). Psikologi Pemaafan. Retrieved April 6, 2013, from http://fatur.staff.ugm.ac.id/file/Psikologi\%20\%20pemaafan.pdf

Worthington, E. (1998). Dimensions of Forgiveness: Psychological Research and Theoretical Perspective. Templeton Foundation. 